\title{
有明海北岸低地で新たに発見された中部更新統の年代と堆積環境
}

\author{
山田圭太郎*+ 日野 剛 徳** 下 山 正一*** \\ 竹 村 恵 二**** 檀 原徹*****岩 野 英 樹*****
}

\section{Age and Sedimentary Environment of Newly Discovered Middle Pleistocene Marine \\ Deposits beneath the Northern Coast Region of Ariake Bay, Kyushu, Japan}

\author{
Keitaro YAMADA*+, Takenori HINO**, Shoichi SHIMOYAMA***, \\ Keiji TAKEMURA ${ }^{* * * *}$, Tohru DANHARA***** and Hideki IWANO*****
}

[Received 26 December, 2012; Accepted 4 June, 2013]

\begin{abstract}
The northern coast of Ariake Bay, which is part of the Tsukushi Plain in Kyushu, Japan, is underlain by thick Quaternary deposits. However, the Late Middle Pleistocene succession had not been found. Recently, the Middle Pleistocene formation (Shagarami Formation) including a tephra bed (Shagarami tephra) was discovered under Aso-3 tephra in a drill core from a site near the mouth of Rokkaku River. This study revealed sedimentary facies of the Shagarami Formation, petrographic characteristics and LA-ICPMS-FT age of the Shagarami tephra. The Shagarami Formation can be divided into two sequence units on the basis of sedimentary facies, and it contains oyster fossils and mud-drape indicative of deposition in marine environments. The Shagarami tephra found in the top of the lower part of the Shagarami Formation mainly comprises pumice, and a zircon LA-ICPMS-FT age of $0.33 \pm 0.06 \mathrm{Ma}(1 \sigma)$ was obtained. Therefore, lower and upper parts of the Shagarami Formation were deposited in different marine transgression and regression sequences in the Late Middle Pleistocene, respectively.
\end{abstract}

Key words : Tsukushi Plain, Middle Pleistocene, Shagarami Formation, Shagarami tephra, fission track age

キーワード : 筑紫平野，中部更新統，社搦層，社搦テフラ，フィッション・トラック年代

* 九州大学理学部地球惑星科学科

** 佐賀大学低平地沿岸海域研究センター

*** 九州大学大学院理学研究院地球惑星科学部門

**** 京都大学大学院理学研究科附属地球熱学研究施設

****** 株式会社京都フィッション・トラック

+ 現所属 : 京都大学大学院理学研究科地球惑星科学専攻

* Department of Earth and Planetary Sciences, School of Sciences, Kyushu University, Fukuoka, 812-8581, Japan

** Institute of Lowland and Marine Research, Saga University, Saga, 840-8502, Japan

*** Department of Earth and Planetary Sciences, Graduate school of Sciences, Kyushu University, Fukuoka, 812-8581, Japan

**** Institute for Geothermal Sciences, Kyoto University, Kyoto, 606-8502, Japan

***** Kyoto Fission-Track Co. Ltd, Kyoto, 603-8832, Japan

+ Present address: Division of Earth and Planetary Sciences, Graduate School of Science, Kyoto University, Kyoto, 606-8502, Japan 


\section{I.はじめに}

わが国における平野地下の第四系の層序学的研 究は，開発や防災などの社会的ニーズのもと，大 阪平野や関東平野などの大都市を中心に活発に研 究が行われてきた (大塚, 1937; 市原, 1960 など)。 これらの第四系は火山灰層などの鍵層に基づき地 域間で対比がなされ（町田ほか, 1980; 中島ほか, 2008 など), 汎世界的な海水準変動を反映した堆 積サイクルが認識されるに至った（市原ほか, 1988; 中澤・遠藤, 2000 など）。

九州地方では, 九州最大の堆積平野である筑紫 平野において 13 万年前以降の堆積物に関して海 水準変動に基づいた研究がなされている（下山ほ か, 1994 など)。一方で中部更新統についての研 究は乏しく，とくに中期更新世後期の堆積層につ いてはこれまで発見されていなかった。原因とし て, 本地域では地下深部に達するボーリング調査 が少ないことに加え，テフラの挟在が少ないこと から，堆積年代が特定できず，中部更新統の分布 の把握が難しいことがあげられる。しかしながら 近年，筑紫平野，とくに有明海北岸地域では道路 建設や農業用水の確保などのインフラ整備や地盤 沈下（国土交通省国土地理院，2001; 鬼塚・根上, 2006 など）や地下水污染（三浦・日野, 2007） などの発生に伴い，地下の第四紀地質への関心が 高まり，地下深部に達するボーリングが行われる ようになってきた。このようなボーリングのう ち, 有明海沿岸道路建設に際して掘削されたボー リングコアから，新たに中期更新世後期の海成層 とそれに含まれるテフラが発見されたので，本稿 で報告する。中期更新世後期の海成層の報告は北 部九州では少なく，これらの発見は有明海北岸地 域の環境変遷やテクトニクスの解明に貢献すると ともに，北部九州と本州の中部更新統を繋ぐ重要 な役割を果たすと考えられる。

\section{II. 有明海北岸低地の地下地質概要}

筑紫平野は九州北部に位置し，六角川・嘉瀬 川・筑後川・矢部川・有明海などが形成した九州 最大の堆積平野である（図 1)。筑紫平野は現在
沈降傾向にあり（下山ほか, 1999)，下山ほか （1994）によると平野部では $50 \mathrm{~m}$ 以上の第四紀 層が厚く堆積しており，とくに有明海北岸地域に おいては $200 \mathrm{~m}$ 以上の第四紀層が厚く堆積して いる。筑紫平野の上部更新統から完新統の地質層 序については，郷原ほか（1964）が陸域部分の 基本層序，有明海研究グループ（1965）が有明海 沿岸部分の基本層序，大島（1977）が白石地域の 地下地質, 福田・砥川（1970）が佐賀地域の地下 地質を報告した。その後，下山ほか（1994）によ りテフラ層序とシーケンス層序に基づく有明海北 岸地域の第四系の記載が行われ，現在はこの区分 が利用されている（図 2)。この層序はボーリング 資料が多数存在する 13 万年前（下山, 2001）に 堆積した阿蘇 3 火砕流堆積物（小野ほか, 1977; 以後Aso-3）以降の堆積層についてシーケンス層 序学に基づき区分されたものである。下山ほか （1994）によれば，有明海北岸地域の地下第四系 は下位から牛屋層, 川副層, Aso-3, 中原層, 高 木瀬層, 阿蘇 4 火砕流堆積物（小野ほか, 1977; 以後, Aso-4), 三田川層, 有明粘土層, 蓮池層 に区分される（図 2)。筑紫平野では MIS 15, $5 \mathrm{e} ， 1$ に相当する海成層が報告されており，それ ぞれ川副層，高木瀬層，有明粘土層にあたる。 下山ほか（1994）はAso-3より下位の中部更新 統と下部更新統については川副層と牛屋層に一括 した。川副層は由布川火砕流堆積物（竹村・檀原， 1993; 以後，Yfg）を含むことから約 60 万年前 （下山ほか, 2012）の堆積物と考えられ，大部分 は陸成層で，一部に固く固結した海成粘土を挟 む。以上のように川副層と上部更新統である中原 層との間にこれまで堆積層は見つかっておらず, 中期更新世後期の有明海周辺の古環境は不明で あった。

\section{III. ボーリングコア概要}

本研究で検討した試料は佐賀県小城市芦刈町道 免社搦 ( $\left.33^{\circ} 12^{\prime} 12.6^{\prime \prime} \mathrm{N}, 130^{\circ} 12^{\prime} 54.6^{\prime \prime} \mathrm{E}\right)$ の標高 $0.84 \mathrm{~m}$ の干拓地（図 1) から孔径 $8.6 \mathrm{~cm}$ で掘削 された全長 $69 \mathrm{~m}$ のボーリングコア（以後，社搦 コア）である。コアは土質試験に一部が使用され 


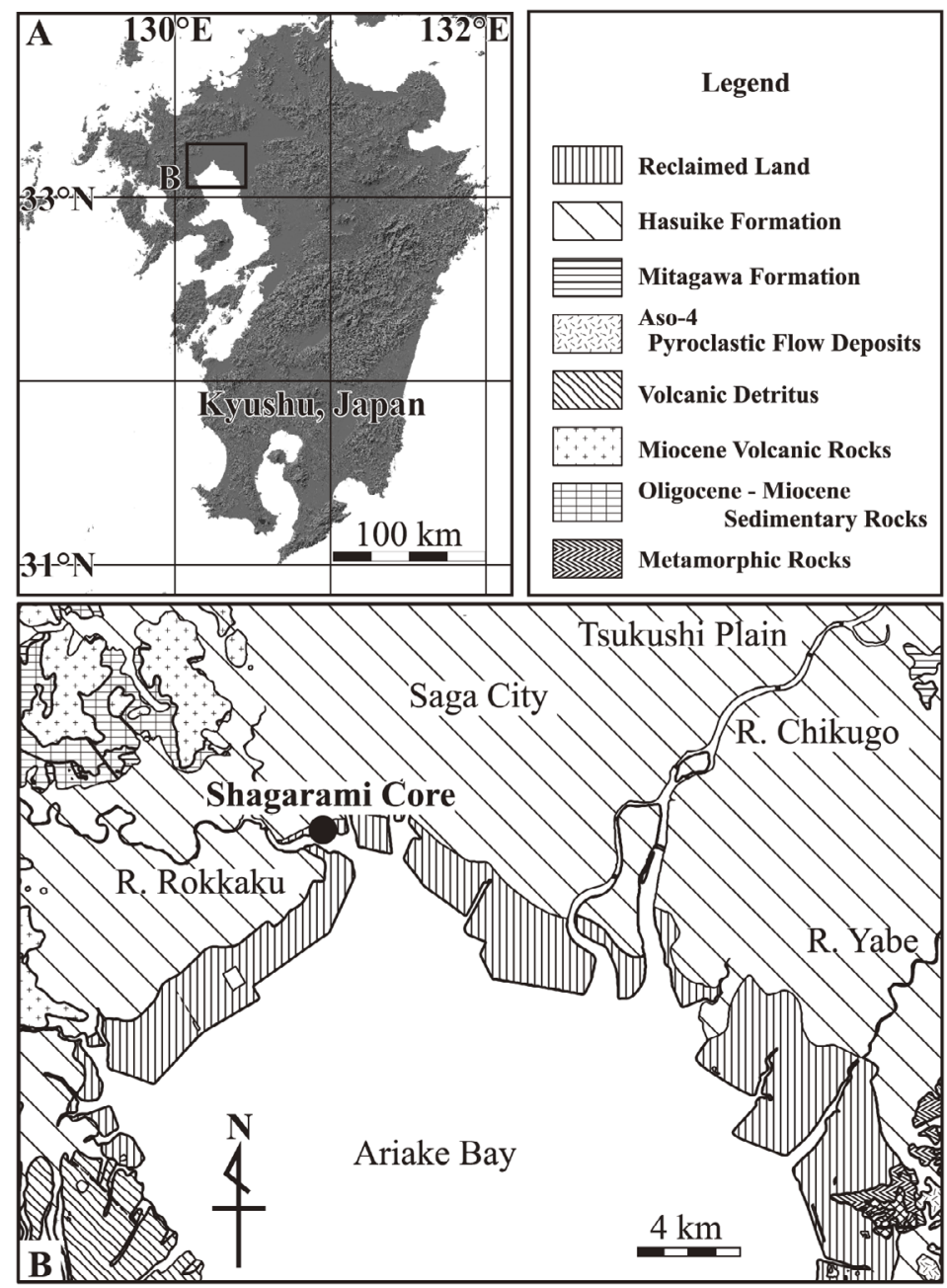

図 1 有明海北岸地域の表層地質図と社搦コアの位置. $\mathrm{A}$ ：カシミール $3 \mathrm{D}$ で描画した九州の地形図. この図の 作成には国土地理院発行の $10 \mathrm{~m}$ メッシュ数值地図標高データを用いた. B : 産業技術総合研究所地質調査 総合センター (2010) に基づく有明海沿岸地域の表層地質図.

Fig. 1 Map showing drill site of Shagarami core. A: Topographic map of Kyushu, Japan, illustrated by KASHMIR 3D. This map is from $10 \mathrm{~m}$ DEM of the Geospatial Information Authority of Japan. B: Geological map of northern coast of Ariake Bay, based on Geological Survey of Japan, AIST (2010).

たため，欠如した部分がある。社搦コアの柱状図 を図 3 に示す。なお，コア久如部分に関しては 基礎地盤コンサルタンツ株式会社九州支社が作成 したボーリング柱状図に基づいて作成した。

社搦コア中からは 4 層のテフラ層が確認され た。各テフラ層は本地域で従来から知られている 広域テフラとの対比から, 深度 $12.80 \sim 12.70 \mathrm{~m}$
のテフラ層は姶良 $\mathrm{Tn}$ 火山灰（町田・新井, 1976; 以後, AT）に，深度 $26.65 \sim 23.70 \mathrm{~m}$ のテフラ 層はAso-4に，深度 $41.55 \sim 39.85 \mathrm{~m}$ のテフラ 層はAso-3 に対比された。ただし，深度 48.55 〜 $48.00 \mathrm{~m}$ に含まれるテフラ層の対比は不明で あった。なお，本研究では深度 $48.55 \sim 48.00 \mathrm{~m}$ から見いだされたテフラ層を社搦テフラ（新称） 


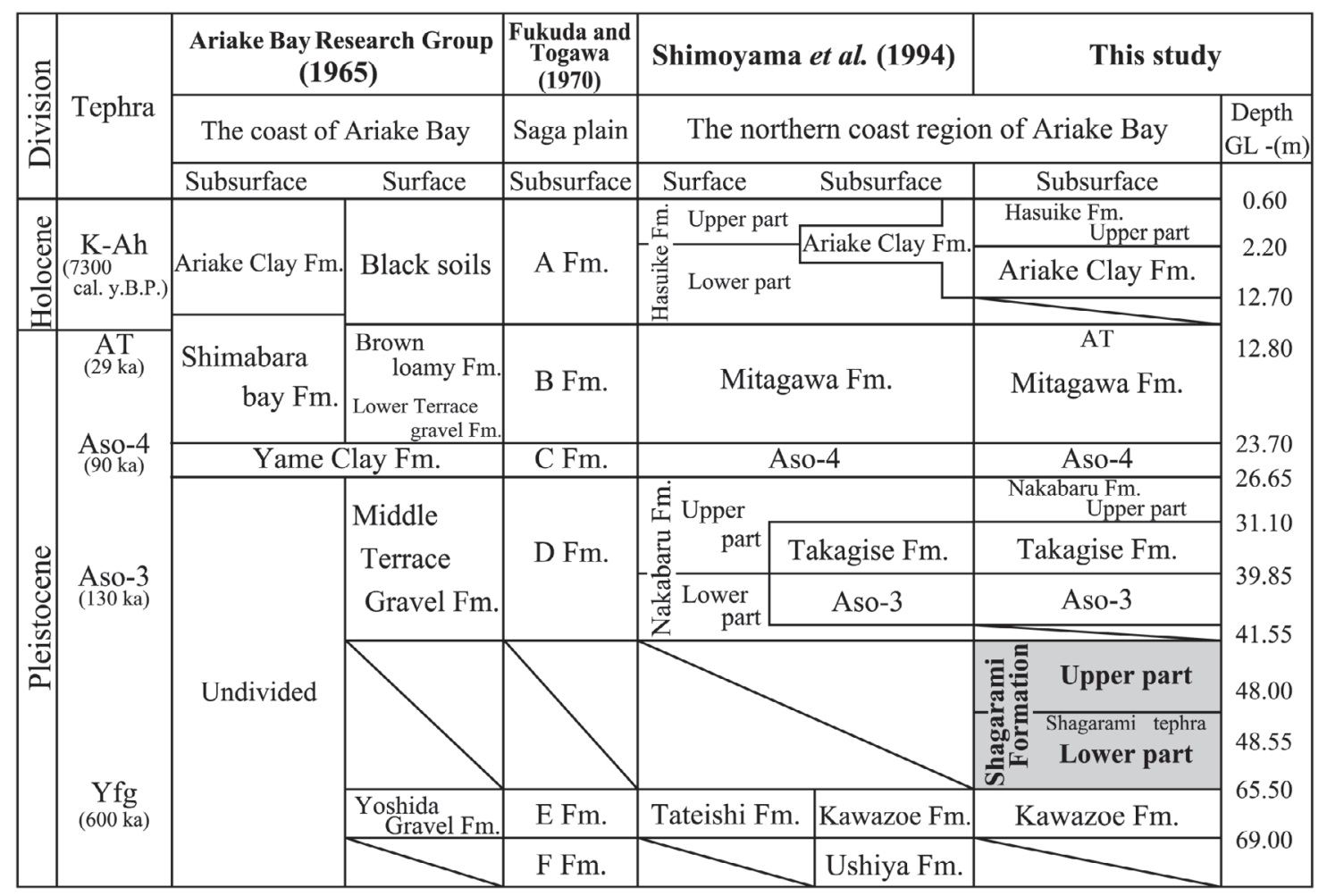

図 2 筑紫平野の第四系層序対比図(下山ほか, 2010 を一部修正).

Fig. 2 Comparison of Quaternary stratigraphic frameworks in the Tsukushi Plain (modified from Shimoyama et al., 2010).

\section{として記載する。}

これらの鍵層をもとに本稿では下山ほか (1994) の定義に従い層序区分を行った。干拓や盛土部分 を除き，ATより上位の海成層を有明粘土層（深度 $12.70 \sim 2.20 \mathrm{~m}$ ), 非海成層を蓮池層上部 (深度 $2.20 \sim 0.60 \mathrm{~m}$ ）とした。Aso-4より上位かつ AT 以下の層準はおもに Aso-4 の再堆積物を中心とす る堆積層で, 三田川層（深度 $23.70 \sim 12.70 \mathrm{~m}$ ) とした。Aso-3 りり上位かつ Aso-4より下位の層 準は, 海成層を高木瀬層（深度 $39.85 \sim 31.10 \mathrm{~m}$ ), 非海成層を中原層上部（深度 $31.10 \sim 26.65 \mathrm{~m}$ ) とした。Aso-3より下位の層準は深度 $65.50 \mathrm{~m}$ の 傾斜不整合を境に著しく層相が変わる。傾斜不整 合より上位かつ Aso-3 より下位の層準は非常に軟 弱で， $N$ 值 5 以下の粘土層を含む。本層は社搦テ フラを含む一方で，下山ほか（1994）や下山ほか
（2010）に記載された川副層の固結度・土色・層 相とは明らかに異なり，川副層に対比されないこ とから，新たな中部更新統と考えられ，社搦層(新 称）と定義した。本層は社搦テフラ層より上位の 層準から層相が著しく変化するため, 深度 65.50 〜 $48.00 \mathrm{~m}$ の層準を社搦層下部，深度 48.00 ～ $41.55 \mathrm{~m}$ の層準を社搦層上部とした。傾斜不整合 より下位の強固結粘土層を含む層準は川副層とし た。本研究ではとくに深度 $65.50 \sim 41.55 \mathrm{~m}$ の社 搦層について詳細に記載し, その堆積年代や堆積 環境などの層序学的位置づけを検討する。

\section{IV. 手 法}

本研究では社搦コアから見いだされた社搦層上 部・下部について，含まれるテフラのフィッショ ン・トラック（FT）年代測定, 記載岩石学的特 


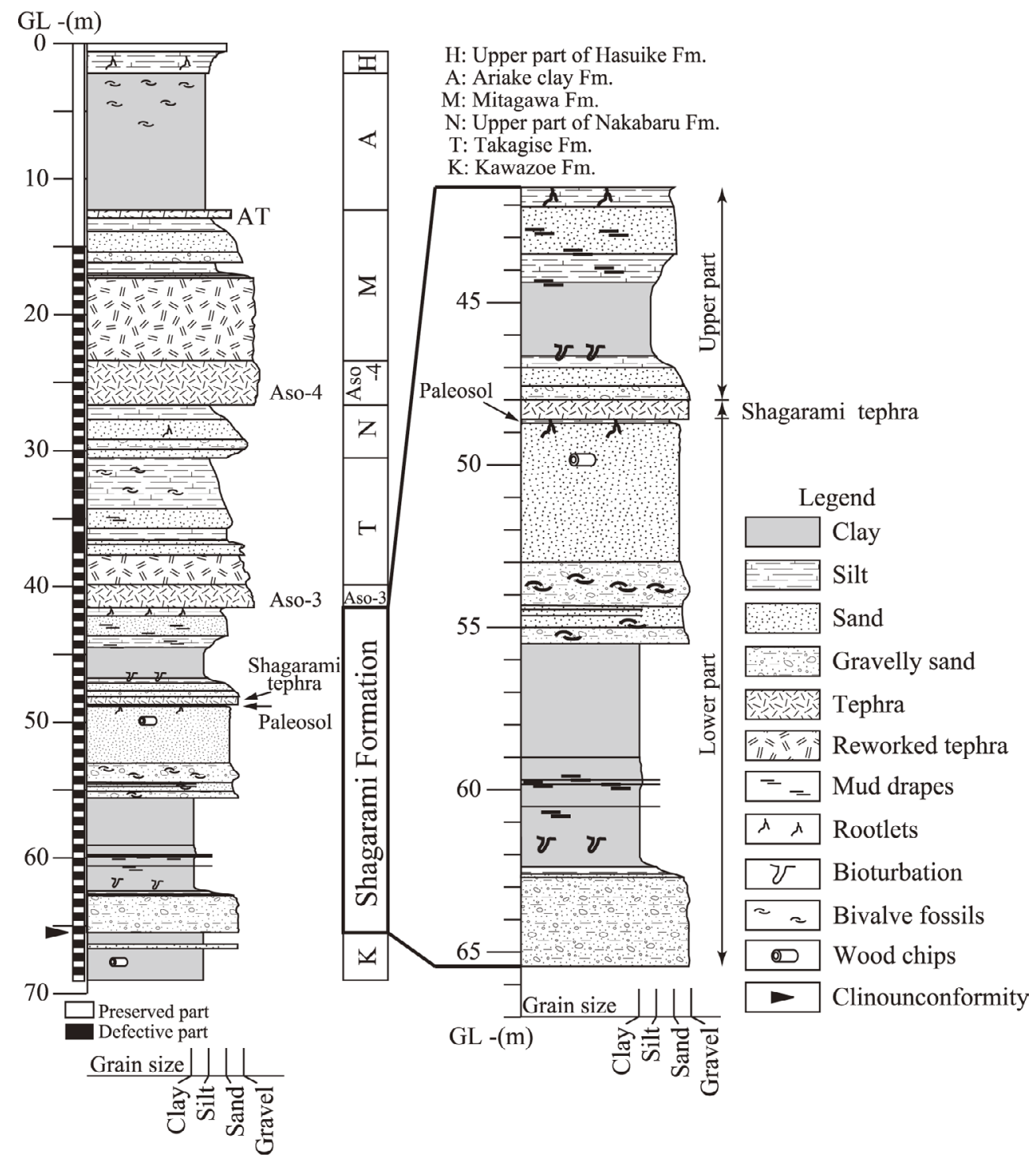

図 3 社搦ボーリングコアの柱状図.

Fig. 3 Columnar sections of Shagarami core.

徵に基づいた広域テフラとの対比，層序学的検討 から堆積年代について検討を行い，堆積構造や大 型化石から堆積環境について地質学的検討を行 い，本層の層序学的位置づけを明確化した。

\section{1) 層相記載}

堆積相については粒度, 堆積構造, 生物擾乱の 有無，大型化石の産出などを記載した。前述の通
り，社搦コアの一部は土質試験に使用され欠如し ているが，それ以外の部分を半割して観察・試料 採取を行い, 欠如部分については基礎地盤コンサ ルタンツ株式会社九州支社が作成したボーリング 柱状図に基づいて記載した。

\section{2) テフラ分析}

テフラに関しては偏光顕微鏡下での観察および 
京都大学が所有する温度変化型屈折率測定装置 (RIMS2000: 株式会社京都フィッション・トラッ ク社製）を用いて，火山ガラス・重鉱物の屈折率 測定を行った。偏光顕微鏡を用いた観察では洗浄 した試料のうち $3 \sim 4 \phi$ の 300 粒子を対象とし, 同定・計数を行い，粒子組成，鉱物組成，火山ガ ラスの形状組成を明らかにした。火山ガラスの形 状分類は吉川（1976）に従い，扁平型 $(\mathrm{H})$, 中 間型 $(\mathrm{C})$, 多孔質型 $(\mathrm{T})$ ，その他 $(\mathrm{O})$ に区分した。 火山ガラス・斜方輝石・普通角閃石の屈折率の測 定はそれぞれ 60 以上の粒子を対象として，檀原 （1993）および鎌田ほか（1994）に従い行った。

\section{3）社搦テフラの FT 年代測定}

社搦テフラに含まれるジルコンに対して FT 法を 用いて年代測定を行った。測定試料は社搦テフラ 約 $71 \mathrm{~g}$ を処理し, 抽出したジルコン 2000 粒子のう ち，ランダムに選んだジルコン 30 粒子を対象とし た。年代測定は檀原（1999）で提案されたレーザー アブレーション型質量分析計 (以後, LA-ICPMS) を用いた LA-ICPMS-FT 法で行った。LA-ICPMSFT 法はジルコンのウラン濃度測定を LA-ICPMS を用いて行うことで原子炉照射に依存せずに年代 測定を行う測定法である（Hasebe et al., 2004）。 年代值の算出はゼー夕較正法 (Hurford, 1990; Donelick et al., 2005）で行い，ウラン濃度デー夕は自 発トラック密度の測定面積に補正した（Donelick et al., 2005)。ウラン濃度の測定は, New Wave 社 製の波長 $193 \mathrm{~nm}$ のエキシマレーザー（径 $35 \mu \mathrm{m} ）$ を用いてサンプリングし， Nu Instruments 社製の 二重収束型 ICPMS 装置で測定した。ウラン濃度 既知の標準試料には 91500 ジルコン（ウラン濃度 80 ppm; Wiedenbeck et al., 1995; Kimura and Chang, 2012), ゼー夕較正用年代標準試料には Fish Canyon Tuff (27.8 $\pm 0.2 \mathrm{Ma}$; Hurford and Hammerschmidt, 1985）を用いた。

\section{V. 記 載}

\section{1）社搦層（新称）}

定義：本層は川副層を傾斜不整合に覆い, Aso-3 に非整合に覆われる粘土・シルト・砂・磎・腐植・ 貝化石・灭山灰から構成される未固結の堆積層で,
社搦テフラ上面を境界として上部と下部に分けら れる。

模式地：佐賀県小城市芦刈町道免社搦の六角川 河口の地下 (社搦コア)。

層厚 : 六角川河口付近において層厚は約 $24 \mathrm{~m}$ 。 分布：佐賀県小城市芦刈町道免社搦周辺。

層相：下部・上部ともに基底は砂礫層からなる が，主部は粘土層・シルト層とその上位の砂磁層 の組み合わせからなる。下部の最上部には砂サイ ズを主体とする火山灰（社搦テフラ）が挟在し， 火山灰層上面を境界として社搦層は上部と下部に 分けられる。

\section{1-1）社搦層下部}

社搦層下部は社搦コアの深度 $65.50 \sim 48.00 \mathrm{~m}$ （標高 $-64.66 〜-47.16 \mathrm{~m}$ ）の部分に相当する。 図 3 に社搦層下部の堆積相を示す。深度 $65.50 \mathrm{~m}$ では，川副層最上部にあたる約 10 度傾斜した粘 土層を直径 $5 \mathrm{~mm}$ 以下の礫を含むほぼ水平に堆 積した社搦層最下部の粗粒砂が傾斜不整合に覆つ ている。媣度 $65.50 \sim 62.60 \mathrm{~m}$ では直径 $5 \mathrm{~mm}$ 以下の砂を含む粗粒砂から粘土へと上方細粒化が 観察される。深度 $62.60 \sim 61.76 \mathrm{~m}$ では塊状無 層理の粘土層が続き，深度 $61.76 \sim 61.50 \mathrm{~m}$ に は生物擾乱によると考えられる $1 \sim 4 \mathrm{~cm}$ のパッ 千状の粗粒砂がしばしば観察される（図 4A）。深 度 $61.50 \sim 61.00 \mathrm{~m}$ では塊状無層理の粘土層が 続き, 深度 $61.00 \sim 59.50 \mathrm{~m}$ では粘土層と砂層 の薄層状互層が観察される。粘土薄層はマッドド レイプ構造（Nichols, 2009 など）と考えられ，と くに深度 $59.70 \mathrm{~m}$ 付近では顕著に観察される。 マッドドレイプの一部には対をなしたダブルマッ ドドレイプも観察される。深度 $59.50 \sim 55.55 \mathrm{~m}$ では塊状無層理の粘土層が続き, 深度 55.55 $53.00 \mathrm{~m}$ では密集したCrassostrea gigas（マガ キ）の化石（図 4B） や直径 $3 \mathrm{~mm}$ 以下の礫を含 む粗砂が観察され，下位の地層を削り込んでい る。深度 $53.00 \sim 48.65 \mathrm{~m}$ では中粒砂が分布し, 深度 $49.80 \mathrm{~m}$ 付近に木片が集中している。深度 48.65 ～ $48.55 \mathrm{~m}$ では腐植物を含む古土㙵層が観 察される (図 4C)。深度 $48.55 \sim 48.00 \mathrm{~m}$ には 社搦テフラが挟在する。社搦テフラは $1 \sim 2 \mathrm{~mm}$ 


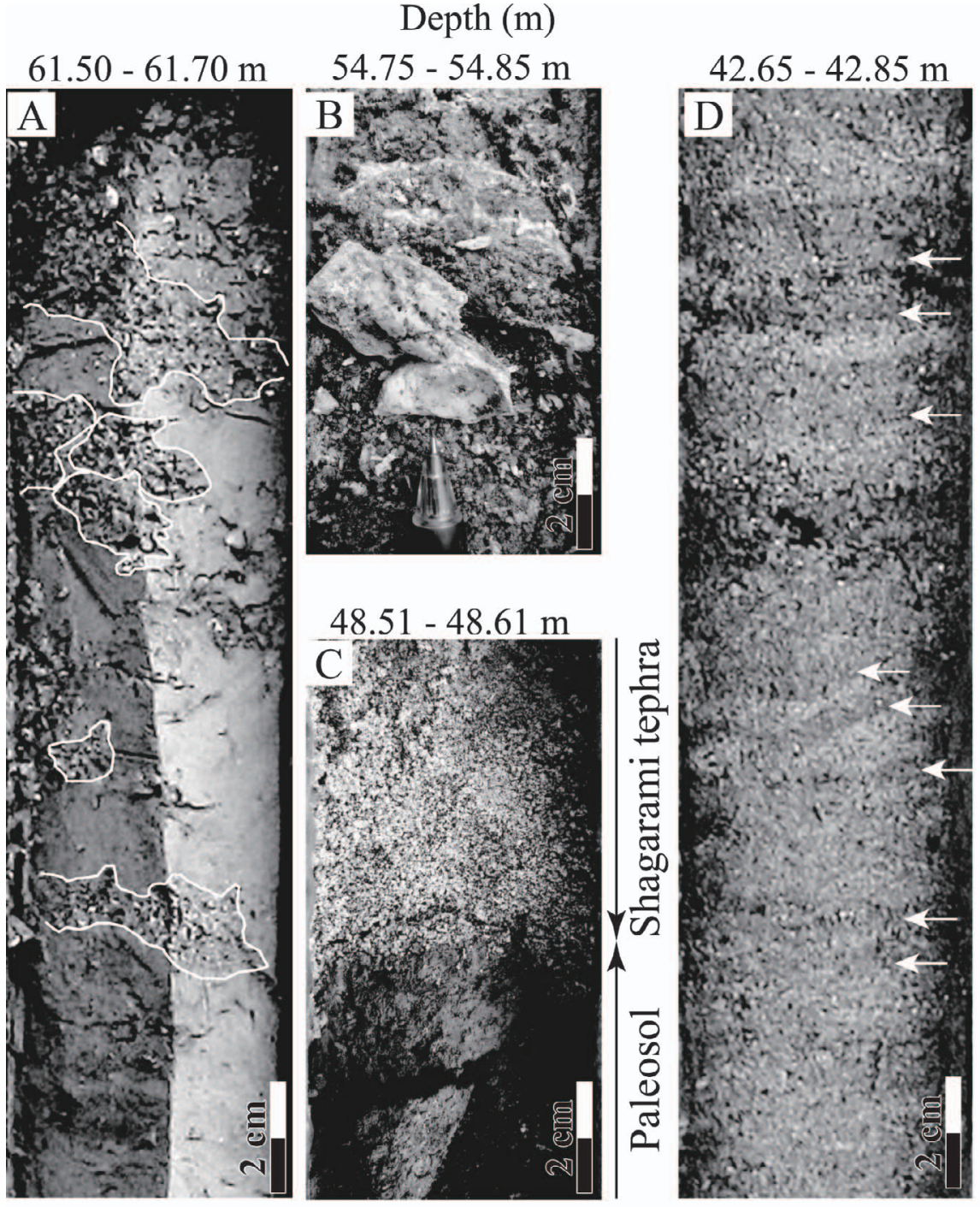

図 4 社搦層のコア写真. $\mathrm{A}$ ：生物擾乱を受けた泥層，社搦層下部. B：マガキ化石を含む䃇質砂層，社搦層下部. C： 古土壤層とそれを覆う社搦テフラ層, 社搦層下部最上部. D : 砂層中に見られるマッドドレイプ, 社搦層下部.

Fig. 4 Photographs of Shagarami Formation. A: Bioturbated mud, lower part of Shagarami Formation. B: Gravelly sand containing fossil of Crassostrea gigas, lower part of Shagarami Formation. C: Shagarami tephra overlying Paleosols, top of lower part of Shagarami Formation. D: Mud drape in sand bed, upper part of Shagarami Formation.

の等粒状の白色軽石からなり，土壤化をほとんど 受けていない（図 4C, 図 5)。

1-2）社搦層上部

社搦層上部は社搦コアの深度 $48.00 \sim 41.55 \mathrm{~m}$
（標高 $-47.16 〜-40.71 \mathrm{~m} ）$ の部分に相当する。 図 3 に社搦層上部の堆積相を示す。深度 $48.00 \mathrm{~m}$ では，社搦層下部最上部に相当する水平に堆積し た社搦テフラ層を，直径 $5 \mathrm{~mm}$ 以下の礫を含む 

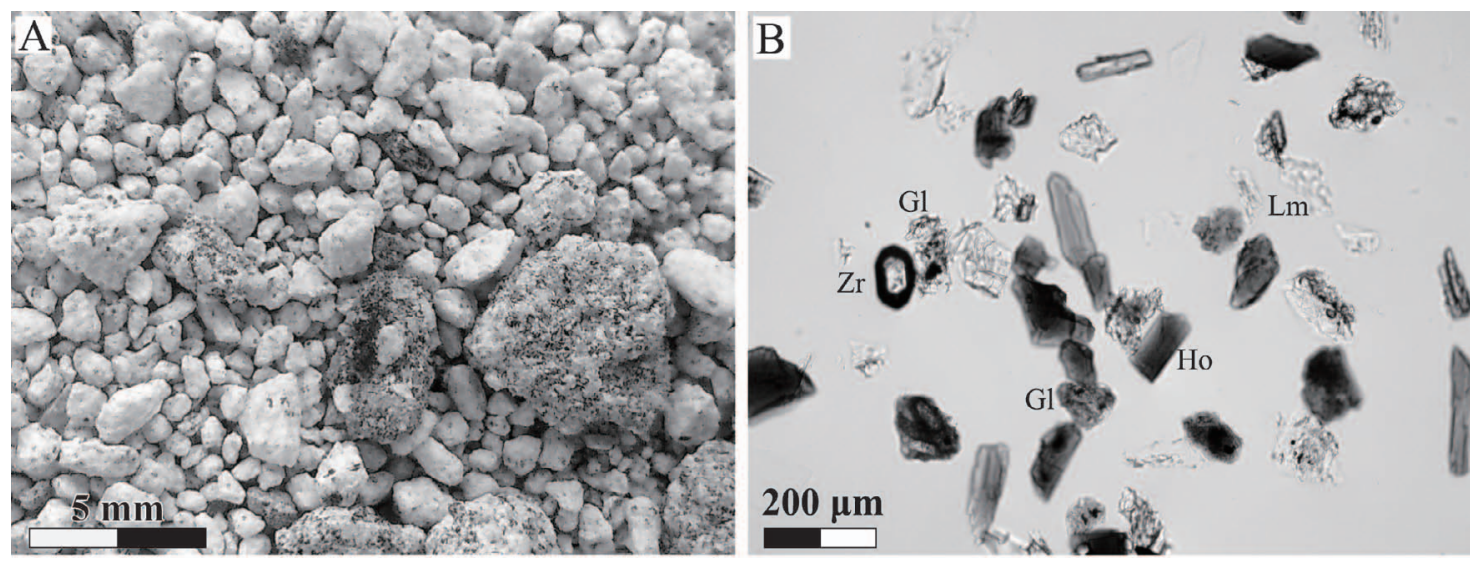

図 5 社搦テフラの写真. $\mathrm{A}$ : 社搦テフラ中の軽石の拡大写真. B : 社搦テフラ構成粒子の偏光顕微鏡写真. 粒子 組成：火山ガラス $(\mathrm{Gl})$, 普通角閃石 $(\mathrm{Ho})$, ジルコン $(\mathrm{Zr})$, 軽鉱物 $(\mathrm{Lm})$.

Fig. 5 Photographs of Shagarami tephra. A: Close-up view of pumice from Shagarami tephra. B: Photomicrograph of constituents of Shagarami tephra. Grain composition: volcanic glass $(\mathrm{Gl})$, hornblende (Ho), zircon ( $\mathrm{Zr}$ ), light mineral $(\mathrm{Lm})$.

表 1 社搦テフラの記載岩石学的特徵.

Table 1 Petrographic properties of Shagarami tephra.

\begin{tabular}{|c|c|c|c|c|c|c|c|c|c|c|c|c|c|c|c|}
\hline \multicolumn{5}{|c|}{ Grain composition (\%) } & \multicolumn{7}{|c|}{ Heavy mineral composition (\%) } & \multicolumn{4}{|c|}{ Shape of glass shards (\%) } \\
\hline $\mathrm{Gl}$ & $\mathrm{Rf}$ & $\mathrm{Lm}$ & $\mathrm{Hm}$ & $\mathrm{Ot}$ & Opx & $\mathrm{Cpx}$ & Ho & $\mathrm{Mg}$ & $\mathrm{Bt}$ & Ap & $\mathrm{Zr}$ & $\mathrm{H}$ & $\mathrm{C}$ & $\mathrm{T}$ & $\mathrm{O}$ \\
\hline 20.1 & 0.6 & 38.3 & 40.3 & 0.7 & 8.3 & 2.5 & 77.5 & 7.5 & 1.7 & 2.5 & $*$ & 2.0 & 44.9 & 52.2 & 0.8 \\
\hline
\end{tabular}

粒子組成: 火山ガラス $(\mathrm{Gl})$, 岩片 $(\mathrm{Rf})$, 軽鉱物 $(\mathrm{Lm})$, 重鉱物 $(\mathrm{Hm})$, その他 $(\mathrm{Ot})$. 重鉱物組成: 斜方輝石 $(\mathrm{Opx})$, 単斜輝石 $(\mathrm{Cpx})$, 普通角閃石 $(\mathrm{Ho})$, 磁鉄鉱 $(\mathrm{Mg})$, 雲母 $(\mathrm{Bt})$, 燐灰石 $(\mathrm{Ap})$, ジルコン $(\mathrm{Zr})$.

火山ガラス形状 : 扁平型 $(\mathrm{H})$, 中間型 $(\mathrm{C})$, 多孔質型 $(\mathrm{T})$, その他 $(\mathrm{O}), *(0.01 \%$ 以下 $)$.

Grain composition, Gl: volcanic glass, Rf: rock fragments, Lm: light mineral, Hm: heavy mineral, Ot: other grains. Heavy mineral composition, Opx: orthopyroxene, Cpx: clinopyroxene, Ho: hornblende, Mg: magnetite, Bt: biotite, Ap: apatite, Zr: zircon. Shape of glass shards, H: flat type, C: middle type, T: porous type, O: other type, ${ }^{*}<0.01 \%$.

ほぼ水平に堆積した粗粒砂が覆っており，この砂 礫層が社搦層上部の基底をなす。哚度 48.00 $46.75 \mathrm{~m}$ には直径 $5 \mathrm{~mm}$ 以下の礫を含む粗粒砂か ら粘土へと上方細粒化が観察される。深度 46.75 〜 $46.50 \mathrm{~m}$ 付近の粘土層中には生物擾乱が観察さ れる。深度 $46.50 \sim 44.80 \mathrm{~m}$ には塊状無層理の粘 土層が続く。深度 $44.80 \sim 43.55 \mathrm{~m}$ では粘土層中 に, 深度 43.55 ～ $42.60 \mathrm{~m}$ では砂層中にマッドドレ イプ構造が観察され (図 4D), とくに深度 $42.70 \mathrm{~m}$ 付近では明瞭に観察される。深度 $42.60 \sim 42.05 \mathrm{~m}$ は砂層で，深度 $42.05 〜 41.55 \mathrm{~m}$ はシルト質粘土
層であり, 植物根痕とみられる線状・パッチ状の変 色帯が観察される。深度 $41.55 \mathrm{~m}$ ではほぼ水平に 堆積したAso-3 と侵食面を伴って非整合に接する。

\section{2) 社搦テフラ (Shg, 新称)}

\section{2-1）記載岩石学的特徵}

社搦テフラの記載岩石学的特徵を表 1 に，写真 を図 5 に示す。社搦テフラは層厚 $55 \mathrm{~cm}$ の淘汰の よい軽石堆積物からなり, 粒径 $1 \sim 2 \mathrm{~mm}$ の発泡 のよい亜角〜亜円の白色軽石を主体とする。石英 や斜長石などの軽鉱物や普通角閃石，斜方輝石， 単斜輝石などの重鉱物を多く含むが，高温石英， 

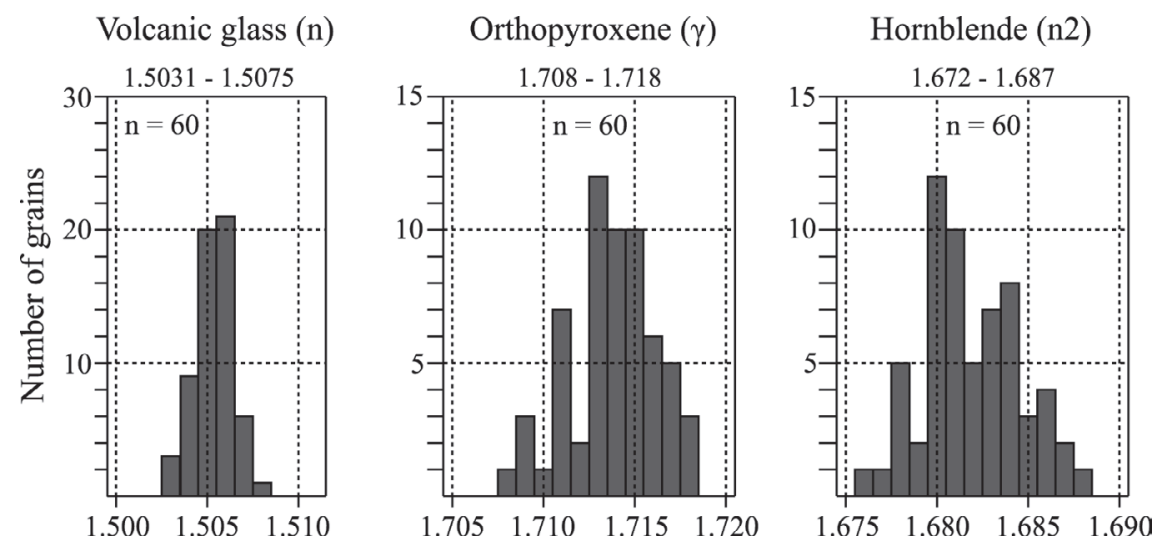

図 6 社搦テフラ中の火山ガラス・斜方輝石・普通角閃石の屈折率分布.

Fig. 6 Histograms showing refractive indices of volcanic glass, orthopyroxene and hornblende contained in Shagarami tephra.

岩片，植物片をほとんど含まない。火山ガラスは 多孔質型や中間型が大半を占め, 扁平型が非常に 少ない (表 1 )。火山ガラス屈折率は $n=1.5031$ 〜 1.5075 (モード : $1.505 \sim 1.506$ ), 斜方輝石の 屈折率は $\gamma=1.708 \sim 1.718$ (モード : 1.713), 普 通角閃石の屈折率は $n 2=1.672 \sim 1.687$ (モード : 1.680) である（図 6)。

\section{2-2) $\mathbf{F T}$ 年代値}

社搦テフラの FT 年代測定結果を表 2 に示す。 年代計算には Fish Canyon Tuff ジルコンの分析 から得られたら值 $40.6 \pm 1.8$ を用いた。本試料の 自発トラック密度は低く, 1 粒子あたりに観察さ れる FT 本数は $0 \sim 3$ 本と非常に少ない。そのた め, 粒子年代は見かけ上バラツキが大きいが， $\chi^{2}$ 検定に合格することから 30 粒子を同一集団とみ なし, 加重平均年代 $0.33 \pm 0.06 \mathrm{Ma}$ を求めた。

\section{VI. 考 察}

\section{1）社搦層下部の堆積環境}

社搦層下部には層厚 $7 \mathrm{~m}$ 以上の粘土層が存在 し，そのなかに生物擾乱やマッドドレイプ構造が 観察され，その直上にはマガキの化石を含む砂層 が確認されることから，深度 $65.50 \sim 53.00 \mathrm{~m}$ の 一連の堆積層は海成層であると判断される。

社搦層下部最下部にあたる深度 $65.50 〜 62.60 \mathrm{~m}$
では上方細粒化が見られる。また，深度 61.76 $61.50 \mathrm{~m}$ の粘土層は, 激しい生物擾乱が観察され ることから，コンデンスセクションに相当すると考 えられる。したがって, 徐々に堆積速度が低下し た可能性があり，海岸からの距離の増加が推定さ れる。深度 $61.00 \sim 59.50 \mathrm{~m}$ では潮流の停潮時に 形成されたと考えられるマッドドレイプ構造が観 察されることから, 潮汐の影響が生じる堆積環境 へと遷移していったと考えられる。深度 $55.55 \mathrm{~m}$ では貝殼が離弁したマガキ化石が下部の粘土層を 削剥し，成層していることから，この粗粒層は干 潟を削り込んだ零筋（潮汐チャネル; Nichols, 2009 など）で堆積したラグ堆積物と考えられる。深度 $49.80 \mathrm{~m}$ では木片を含む砂層が観察されることか ら，河川の影響が強い環境へと遷移していったと 考えられる。深度 48.65 ～ $48.55 \mathrm{~m}$ では古土壤 層が観察されることから離水・陸化し, その後土 壤化したと考えられる。社搦テフラは，この古土 壤層を覆って厚く堆積している。社搦テフラは淘 汰がよく，岩片や植物片などをほとんど含まな い。社搦テフラは亜角〜亜円の軽石を多く含み, 若干の摩耗が見られるが，降下中の粒子衝突によ る摩耗や堆積後の風化の影響で十分説明できるた め，再堆積による摩耗の可能性は低い。したがっ て，社搦テフラは降下軽石堆積物であると考えら 
表 2 社搦テフラ中のジルコン FT 年代.

Table 2 Fission track age of zircon crystals of Shagarami tephra.

\begin{tabular}{|c|c|c|c|c|c|c|c|c|c|c|}
\hline \multirow{3}{*}{ Sample No. } & \multirow{3}{*}{$\begin{array}{l}\text { Surface/ } \\
\text { grain }\end{array}$} & \multicolumn{4}{|c|}{ sample } & \multicolumn{2}{|c|}{ standard (91500) } & \multirow{3}{*}{$\begin{array}{c}\operatorname{Pr}\left(\chi^{2}\right) \\
(\%)\end{array}$} & \multirow{3}{*}{$\begin{array}{c}\mathrm{U} \\
(\mathrm{ppm})\end{array}$} & \multirow{3}{*}{$\begin{array}{l}\text { Fission track ag } \\
\quad \pm 1 \sigma(\mathrm{Ma})\end{array}$} \\
\hline & & \multicolumn{2}{|c|}{ Spontaneous track } & \multicolumn{2}{|c|}{ Total ${ }^{238} \mathrm{U}$-count } & \multicolumn{2}{|c|}{ Mean ${ }^{238} \mathrm{U}$-count per LA } & & & \\
\hline & & $\rho_{\mathrm{S}}\left(\right.$ per $\left.\mathrm{cm}^{-2}\right)$ & $\left(\Sigma N_{S}\right)$ & $\rho_{\mathrm{U}}\left(\right.$ per $\left.\mathrm{cm}^{-2}\right)$ & $\left(\Sigma N_{U}\right)$ & $\rho_{\mathrm{U}(\mathrm{st})}\left(\right.$ per $\left.\mathrm{cm}^{-2}\right)$ & $\left(N_{U(s t)}\right)$ & & & \\
\hline $\begin{array}{c}\text { Shagarami } \\
\text { tephra }\end{array}$ & $\begin{array}{c}\text { External/ } \\
30\end{array}$ & $2.19 \times 10^{4}$ & (30) & $2.74 \times 10^{11}$ & $(376023630)$ & $1.014 \times 10^{11}$ & (973629) & 37 & 230 & $0.33 \pm 0.06$ \\
\hline
\end{tabular}

FT の計数はジルコンの外部表面で行い, ウラン濃度の測定はレーザーアブレーション型質量分析計 (LA-ICPMS) を用いた。ウラン濃度の標準試料として Nancy91500 ジルコン (80 ppm; Wiedenbeck et al., 1995; Kimura and Chang, 2012) を用いた。 ゼー夕較正用年代標準試料には Fish Canyon Tuff $(27.8 \pm 0.2 \mathrm{Ma}$; Hurford and Hammerschmidt, 1985）を用い, そこから得られたら值 $40.6 \pm 0.8$ を採用した.

$\rho_{\mathrm{s}}$ : 自発トラック密度, $\rho_{\mathrm{U}}:{ }^{238} \mathrm{U}$ カウント密度, $\operatorname{Pr}\left(\chi^{2}\right): \chi^{2}$ 值の自由度 (n-1; Galbraith, 1981).

Track counting was applied to external surfaces of zircon. Uranium content measurement was carried out using an excimer-laser ablation ICP mass spectrometry (LA-ICPMS). Nancy 91500 zircon with 80 ppm uranium (Wiedenbeck et al., 1995; Kimura and Chang, 2012) was used as an external standard. Laser power, repetition, ablation pit size and integration time were $30 \%, 8 \mathrm{~Hz}, 35 \mathrm{~mm}$ and $10 \mathrm{~s}$, respectively. Spontaneous track density $\left(\rho_{\mathrm{s}}\right)$ equals $\Sigma \mathrm{Ns} / \Sigma$ $\mathrm{S}$ where $\Sigma \mathrm{Ns}$ is the total number of spontaneous tracks counted over area $\Sigma \mathrm{S}$. $\rho_{\mathrm{U}}$ is an areal density of ${ }^{238} \mathrm{U}$-count analyzed by LA-ICPMS. Total ${ }^{238} \mathrm{U}$-count data for sample were corrected ones as the same area as $\Sigma \mathrm{S}$, and ${ }^{238} \mathrm{U}$-count for standard was a mean value of laser ablation (LA) analyses throughout session. $\operatorname{Pr}\left(\chi^{2}\right)$ is the probability of obtaining the $\chi^{2}$ value for $n$ degrees of freedom $(n=$ number of crystals -1 ; Galbraith, 1981). A $\zeta$-value of $40.6 \pm$ 1.8 was obtained by analyzing the Fish Canyon Tuff zircon with reference age of $27.8 \pm 0.2 \mathrm{Ma}$ (Hurford and Hammerschmidt, 1985), and used for calibration.

れる。また社搦テフラは再堆積物ではないこと, 下位の古土壤が削剥されずに保存されていること を考慮すると，社搦テフラと古土壤の間に異なる 海進期が存在したとは考えにくい。以上のことか ら, 社搦層下部は一連の海進・海退に伴い堆積し たと考えられ, 社搦テフラは社搦層下部の堆積後 の高海水準期後期〜低海面期に堆積したと考えら れる。

\section{2）社搦層上部の堆積環境}

社搦層上部の層厚 $4 \mathrm{~m}$ 程度の粘土・シルト層 中に生物擾乱やマッドドレイプ構造が観察される こと, 層厚 $1 \mathrm{~m}$ 程度の砂層中にマッドドレイプ構 造が観察されることから，深度 $48.00 \sim 41.55 \mathrm{~m}$ の一連の堆積層は海成層であると判断される。

社搦層上部最下部は社搦テフラの直上に水平に 堆積している。社搦テフラが土壤化・風化してい ないことを考慮すると, 社搦層上部は社搦テフラ の堆積後，大きな時間間隙をおかず堆積したと考 えられ, 社搦層下部の堆積直後に引き続く海進期 に堆積し，社搦テフラ層とは非整合で接している と考えられる。社搦層上部は深度 $48.00 \sim 46.75 \mathrm{~m}$
に砂砂層〜シルト層への上方細粒化が観察される。 また, 深度 $46.75 \sim 46.50 \mathrm{~m}$ の粘土層は, 生物擾 乱が観察されることから，コンデンスセクションに 相当すると考えられる。したがって, 徐々に堆積 速度が低下した可能性があり, 海岸からの距離の 増加が推定される。深度 $44.80 \sim 42.60 \mathrm{~m}$ ではマッ ドドレイプ構造が観察され，潮汐の影響が示唆さ れることから, 堆積環境は潮汐の影響が生じる水 深へ遷移していったと考えられる。一方，深度 $42.05 \sim 41.55 \mathrm{~m}$ では植物根痕を含む粘土層が観 察されることから，最終的には陸化・湿地化した と考えられる。以上のことから, 社搦層上部は社 搦テフラ堆積直後の一連の海進・海退に伴い堆積 したと考えられる。

\section{3) 社搦テフラの年代と対比}

社搦テフラは古土㙥の上に堆積した降下テフラ であること, FT 年代值およびその䛊差（0.33土 $0.06 \mathrm{Ma})$ を考慮すると，MIS 10 もしは 8 の 低海水準期に堆積したと考えられる。このこと は，社搦テフラが約 60 万年前に堆積した Yfg を 含む川副層より上位で，かつ約 13 万年前に堆積 
したAso-3 より下位に位置することとも矛盾しな い。社搦テフラは，陸上に $50 \mathrm{~cm}$ 程度堆積してい ることや軽石を主体とする等粒状のテフラである ことを考慮すると，高い噴煙柱に由来するプリ ニー式噴火による堆積物と考えられ，広域に分布 している可能性がある。しかしながら，火山ガラ ス・斜方輝石・普通角閃石屈折率や記載岩石学的 特徵, 噴出年代值から社搦テフラの広域対比を試 みたが，対比できるテフラは特定できなかった。

\section{4）社搦層下部と社搦層上部の堆積年代と対比}

社搦層上部の海成層は社搦テフラ層の上位かつ Aso-3 テフラ層の下位に位置することから，社搦 テフラの FT 年代值とその誤差およびAso-3 の堆 積年代を考慮すると，40～13 万年前に堆積され たと考えられ，MIS 9 もしくはMIS 7 の海進期 から高海水準期に堆積したと考えられる。

社搦層下部の海成層は MIS 10 あるいは MIS 8 に降下したと考えられる社搦テフラに覆われるこ とから，MIS $11 も し く は$ MIS 9 の海進期から高 海水準期に堆積したと考えられる。これは川副層 と社搦層の間には傾斜不整合が存在し，時間間隙 が存在することとも矛盾しない。

したがって社搦層は MIS 12 ～ 7 の間のいずれ か 2 回の海進・海退サイクルに伴い形成された と考えられ, 今後北部九州の古環境や古気候を復 元するにあたって社搦層は非常に重要な役割を果 たすと考えられる。

\section{VII. ま と}

本研究では，有明海北岸地域に位置する六角川 河口付近で掘削されたボーリングコアにおいて, 新たに中部更新統を見いだし，社搦層と命名し た。社搦層について, 層序, 堆積構造・大型化石 の記載，狭在するテフラについて FT 年代測定， 記載岩石学的特徵の検討を行い, 以下の点を明ら かにした。

（1）社搦層は，社搦テフラ層の上面を境に下部 と上部に分けられ，マッドドレイプ構造，生物擾 乱，マガキ化石が産出することなどから，それぞ れ異なる海進期に堆積した海成層を含むと考えら れる。
（2）社搦層下部の最上部からは降下軽石堆積 物を主体とするテフラ層（社搦テフラ層）が発見 された。層序学的検討および FT 年代值から社搦 テフラは $0.33 \mathrm{Ma}$ 前後の低海水準期に堆積した と考えられる。

（3）社搦層下部と社搦層上部に含まれる海成 層は層序学的検討と社搦テフラの年代值に基づく と, 中期更新世後期のそれぞれ異なる海進期〜高 海水準期に堆積したと考えられる。

\section{謝 辞}

本研究を行うにあたり，佐賀県有明海沿岸道路整備 事務所にはボーリングコア試料（社搦コア）とボーリ ングコア柱状図資料を提供していただいた。福富ボー リングコア，川副ボーリングコア試料抢よびボーリン グ柱状図の入手にあたっては国土交通省福岡国道事務 所有明海沿岸道路出張所の皆様に大変お世話になった。 基礎地盤コンサルタンツ株式会社九州支社の皆様には コア観察やサンプリングにあたり多大なるご助力をい ただいた。京都大学大学院理学研究科の平田岳史教授 には LA-ICPMS-FT 年代の測定にあたり御助力をいた だいた。京都大学大学院理学研究科の堤 浩之准教授 には，テフラの屈折率測定にあたり RIMS2000を使用 させていただいた。京都大学理学研究科の石村大輔氏 には RIMS2000 の使用方法について御教授いただき， また論文作成にあたり多大なるご助言をいただいた。 九州大学大学院理学府の二宮 崇氏, 筒井英人氏には 論文作成にあたり御助言をいただいた。九州大学理学 部の北野一平氏，長原正人氏にはサンプリングにあた りご協力いただいた。京都大学理学研究科の James Ashworth 氏には英文を校閲していただいた。また本研 究を進める上で編集担当委員抒よび 2 名の查読者の 方々には貴重なご指摘をいただいた。ご支援をいただ いた以上の方々に記して謝意を表する。なお，本研究 では平成 23 年度松本達郎教授奨学資金による援助をい ただいた。本資金をご寄付された故松本達郎名誉教授 には厚くお礼申し上げる。

\section{文献}

有明海研究グループ (1965): 有明・不知火海域の第四 系. 地団研専報，11，86p. [Ariake Bay Research Group (1965): Quaternary system of the Ariake and the Shiranui Bay areas, with special reference to the Ariake soft clay. Monograph of the Association for the Geological Collaboration, 11, 86p. (in 
Japanese with English abstract) ]

檀原 徹 (1993): 温度変化型屈折率測定法. 日本第四 紀学会編：第四紀試料分析法 2 研究対象別分析法. 東京大学出版会, 149-158. [Danhara, T. (1993): Refractive index measurement using thermal immersion method. in A Handbook of Quaternary Research edited by Japan Association for Quaternary Research, University of Tokyo Press, 149-158. (in Japanese) *]

檀原 徹 (1999): ジルコンを用いた第四紀試料の高精 度 $\mathrm{FT}$ 年代測定の現状と将来. 月刊地球号外, 26 , 70-76. [Danhara, T. (1999): The present conditions and the future of the high precise FT dating of the Quaternary sample using the zircon. Chikyu Monthly Extra, 26, 70-76. (in Japanese) *]

Donelick, R.A., O'Sullivan, P.B. and Ketcham, R.A. (2005): Apatite fission-track analysis. Review in Mineralogy and Geochemistry, 58, 49-94.

福田理・砥川隆二 (1970): 佐賀平野の地質と佐賀市 の地盤沈下。地質ニュース，193，14-31. [Fukuda, O. and Togawa, R. (1970): Geology of Saga Plain and Land subsidence of Saga City. Chishitsu News, 193, 14-31. (in Japanese) *]

Galbraith, R.F. (1981): On statistical models for fission track counts. Mathematical Geology, 13, 471478.

郷原保真 - 新堀知行 - 鈴木康司 - 野村 哲 - 小森長生 (1964): 北九州の第四紀層に関する諸問題。資源科学 研究所彙報，62，83-108. [Gohara, Y., Nihbori, T. Suzuki, K., Nomura, S. and Komori, T. (1964): Problems about Quaternary in Northern Kyushu. Miscellaneous Reports of Research Institute for Natural Resources, 62, 83-108. (in Japanese)*]

Hasebe, N., Barbarand, J., Jarvis, K., Carter, A. and Hurford, A.J. (2004): Apatite fission-track chronometry using laser ablation ICP-MS. Chemical Geology, 207, 135-145.

Hurford, A.J. (1990): Standardization of fission track dating calibration: Recommendation by the Fission Track Working Group of the I.U.G.S. Subcommission of Geochronology. Chemical Geology, 80, 171178.

Hurford, A.J. and Hammerschmidt, K. (1985): ${ }^{40} \mathrm{Ar} /{ }^{39} \mathrm{Ar}$ and dating of the bishop and fish canyon tuffs: Calibration ages for fission-track dating standards. Chemical Geology, 58, 23-32.

市原 實 (1960): 大阪，明石地域の第四紀層に関する 諸問題. 地球科学, 49, 15-25. [Ichihara, M. (1960): Some problems of the Quaternary sedimentaries, Osaka and Akasi Areas. Earth Science (Chikyu Kagaku), 49, 15-25. (in Japanese with English abstract)]

市原 実・吉川周作・亀井節夫 · 那須孝悌 (1988): 近 畿地方の第四紀層の層序区分. 地質学論集, $\mathbf{3 0}$, 111-125. [Ichihara, M., Yoshikawa, S., Kamei, S. and Nasu, T. (1988): Stratigraphic subdivision of Quaternary deposits in Kinki district, Japan. Mem- oirs of the Geological Society of Japan, 30, 111-125. (in Japanese with English abstract) ]

鎌田浩毅・檀原 徹 - 山下 透 - 星住英夫 ·林田 明 竹村恵二 (1994): 大阪層群アズキ火山灰および上総 層群 Ku6 火山灰と中部九州の今市火砕流堆積物との 対比一猪牟田カルデラから噴出した co-ignimbrite ash一。地質学雑誌，100，848-866. [Kamata, H., Danhara, T., Yamashita, T., Hoshizumi, H., Hayashida, A. and Takemura, K. (1994): Correlation of the Azuki volcanic ash of the Osaka Group and the Ku6C volcanic ash of the Kazusa Group to the Imaichi pyroclastic-flow deposit in central Kyushu, Japan: A co-ignimbrite ash erupted from Shishimuta caldera. Journal of the Geological Society of Japan, 100, 848-866. (in Japanese with English abstract) ]

Kimura, J. and Chang, Q. (2012): Origin of the suppressed matrix effect for improved analytical performance in determination of major and trace elements in anhydrous silicate samples using $200 \mathrm{~nm}$ femtosecond laser ablation sector-field inductively coupled plasma mass spectrometry. Analytical Atomic Spectrometry, 27, 1549-1559.

国土交通省国土地理院 (2001): 佐賀地方地盤変動調査 測量に関する報告，28. [Geospatial Information Authority of Japan (2001): Report of Survey for Ground Deformation in Saga Region (Saga Chiho Jiban Hendo Chosa Sokuryo Ni Kansuru Hokoku), 28. (in Japanese) *]

町田 洋・新井房夫 (1976): 広域に分布する火山灰一 姶良 $T n$ 火山灰の発見とその意義一。科学, 46, 339-347. [Machida, H. and Arai, F. (1976): The discovery and significance of the very widespread tephra: The Aira-Tn ash. Kagaku, 46, 339-347. (in Japanese) *]

町田 洋・新井房夫・杉原重夫 (1980): 南関東と近畿 の中部更新統の対比と編年一テフラによる一つの試 み一. 第四紀研究, 19, 233-261. [Machida, H., Arai, F. and Sugihara, S. (1980): Tephrochronological study on the middle Pleistocene deposits in the Kanto and Kinki districts, Japan. Quaternary Research, 19, 233-261. (in Japanese with English abstract) ]

三浦哲彦・日野剛徳 (2007): 最近の深層混合処理工法 と環境保全. 総合土木研究所編：軟弱地盤の改良 (12), 1-10. [Miura, N. and Hino, T. (2007): Recent deep line mixing method and environmental conservation in Improvement of the Soft Ground (12) (Nanjaku Jiban No Kairyo (12)) edited by Sogo Doboku Kenkyusho, 1-10. (in Japanese) * ]

中島 礼・水野清秀・古澤 明 (2008): テフラ対比に 基づく中部更新統渥美層群の堆積年代. 地質学雑誌, 114, 70-79. [Nakashima, R., Mizuno, K. and Furusawa, A. (2008): Depositional age of the Middle Pleistocene Atsumi Group in Atsumi Peninsula, central Japan, based on tephra correlation. Journal of the Geological Society of Japan, 114, 70-79. (in 
Japanese with English abstract)]

中澤 努·遠藤秀典 $(2000)$ : 関東平野中央部「野田」「大 宮」地域の更新統シーケンス層序と構造運動. 地質調 査所月報， 51，411-415. [Nakazawa, T. and Endo, H. (2000): Pleistocene sequence stratigraphy and tectonic movements in the Noda and Omiya districts, central Kanto Plain. Bulletin of the Geological Survey of Japan, 51, 411-415. (in Japanese with English abstract) ]

Nichols, G. (2009): Sedimentology and Stratigraphy Second Edition. Wiley-Blackwell, 168-169.

鬼塚克忠・根上武仁 (2006) : 筑紫平野の有明海沿岸部 の地盤沈下. 土木学会論文集 C, 62, 643-656.

[Onitsuka, K. and Negami, T. (2006): Ground subsidence in coast area of Ariake Bay, Chikugo Plain. Journal of Japan Society of Civil Engineers, Ser. C, 62, 643-656. (in Japanese with English abstract)]

小野晃司・松本柾夫 - 宮久三千年 - 寺岡易司 - 神戸 信伸 (1977): 竹田地域の地質。地域地質研究報告 (5 万分の 1 地質図幅)。地質調查所. [Ono, K., Matsumoto, Y., Miyahisa, M., Teraoka, Y. and Kambe, N. (1977): Geology of the Taketa District. Quadrangle Series, 1:50,000. Geological Survey of Japan. (in Japanese with English abstract)]

大島恒彦 (1977): 佐賀平野の地盤沈下。土と基礎, 25, 69-74. [Ohshima, T. (1977): The Land subsidence of Saga Plain. Soil Mechanics and Foundation Engineering, 25, 69-74. (in Japanese)*]

大塚弥之助 (1937): 関東地方南部の地質構造「横浜-藤 沢間」. 東京帝国大学地震研究所彙報, 15, 9741040. [Otuka, Y. (1937): Geologic structure of the south Kwanto region, Japan. Bulletin of the Earthquake Research Institute, Tokyo Imperial University, 15, 974-1040. (in Japanese with English abstract) ]

産業技術総合研究所地質調査総合センター編 (2010): 20 万分の 1 日本シームレス地質図データベース (2010 年 11 月 11 日版). 産業技術総合研究所研究情 報公開データベース DB084. [Geological Survey of Japan, AIST ed. (2010): Seamless digital geological map of Japan 1: 200,000. Jun 29, 2011 version. Research Information Database DB084.]

下山正一 (2001): 低平地地下における阿蘇 3 火砕流堆 積物（Aso-3）の年代について. 低平地研究, 10, 32-38. [Shimoyama, S. (2001): Age of Aso-3 pyroclastic flow deposit under low-land, Kyushu, Japan. Research on Lowland Technology, 10, 32-38. (in Japanese)*]

下山正一 - 松本直久 ·湯村弘志 - 竹村恵二 · 岩尾雄四 郎・ 三浦哲彦・陶野郁雄 (1994): 有明海北岸低地の 第四系. 九州大学理学部研究報告地球惑星科学, 18, 103-129. [Shimoyama, S., Matsumoto, N., Yumu- ra, H., Takemura, K., Iwao, Y., Miura, N. and Tohno, I. (1994): Quaternary geology of the low-land along the north coast of Ariake Bay, West Japan. Science Reports, Department of Earth and Planetary Sciences, Kyushu University, 18, 103-129. (in Japanese with English abstract)]

下山正一・木下裕子・宮原百々・田中ゆか里・市原 季彦・竹村恵二 (1999): 旧汀線高度からみた九州の 後期更新世地殼変動様式. 地質学雑誌, 105, 311331. [Shimoyama, S., Kinoshita, H., Miyahara, M., Tanaka, Y., Ichihara T. and Takemura, K. (1999): Mode of vertical crustal movements during Late Quatenary in Kyushu, Japan deduced from heights of ancient shorelines. Journal of the Geological Society of Japan, 105, 311-331. (in Japanese with English abstract)]

下山正一・松浦浩久 ・日野剛徳 (2010): 佐賀地域の地質. 地域地質研究報告 (5 万分の 1 地質図幅)。産業技術 総合研究所地質調査総合センター. [Shimoyama, S., Matsuura, H. and Hino, T. (2010): Geology of the Saga District. Quadrangle Series, 1:50,000. Geological Survey of Japan, AIST. (in Japanese with English abstract) ]

下山正一 - 松浦浩久 · 水野清秀 - 窪田正和 - 日野剛徳 · 檀原 徹 · 岩野英樹 · 山下 透 ·二宮 崇 (2012) : 有明海周辺から 0.6 Ma 前後を示す指標テフラの発見 とその意義. 地質学雑誌, 118, 709-722. [Shimoyama, S., Matsuura, H., Mizuno, K., Kubota, M., Hino, T., Danhara, T., Iwano, H., Yamashita, T. and Ninomiya, T. (2012): Discovery of an Middle Pleistocene marker tephra around the Ariake Bay area, Southwest Japan. Journal of the Geological Society of Japan, 118, 709-722. (in Japanese with English abstract) ]

竹村恵二・檀原 徹 (1993): 由布川火砕流のフィッショ ン・トラック年代. 火山, 38, 63-66. [Takemura, K. and Danhara, T. (1993): Fission-track age of Yufugawa pyroclastic flow deposit, Oita prefecture, Japan. Bulletin of the Volcanological Society of Japan, 38, 63-66. (in Japanese with English abstract) ]

Wiedenbeck, M., Alle, P., Corfu, F., Griffin, W.L., Meier, M., Oberli, F., Van Quadt, A., Roddick, J.C. and Spiegel, W. (1995): Three natural zircon standards for U-Th-Pb, Lu-Hf, trace element and REE analyses. Geostandards Newsletter, 19, 1-23.

吉川周作（1976）: 大阪層群の火山灰層について．地質 学雑誌, 82, 497-515. [Yoshikawa, S. (1976): The volcanic ash layers of the Osaka Group. Journal of the Geological Society of Japan, 82, 497-515. (in Japanese with English abstract) ]

* Title etc. translated by K.Y. 